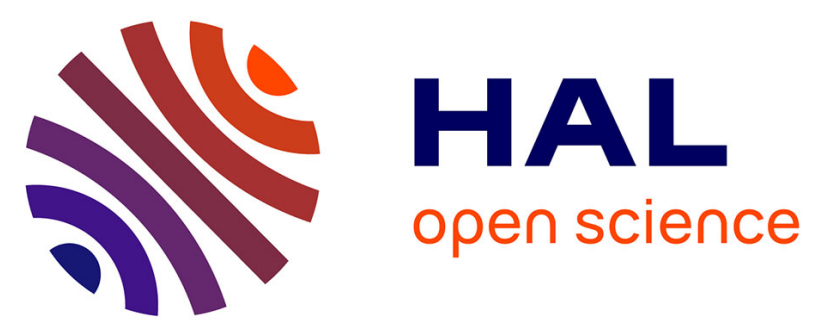

\title{
Problems encountered during the up-grading transformation of the FN-tandem of Saclay
}

L. Bianchi, B. Delaunay, J.P. Fouan, J. Gastebois, J.L. Girma

\section{To cite this version:}

L. Bianchi, B. Delaunay, J.P. Fouan, J. Gastebois, J.L. Girma. Problems encountered during the up-grading transformation of the FN-tandem of Saclay. Revue de Physique Appliquée, 1977, 12 (10), pp.1431-1433. 10.1051/rphysap:0197700120100143100 . jpa-00244342

\section{HAL Id: jpa-00244342 https://hal.science/jpa-00244342}

Submitted on 1 Jan 1977

HAL is a multi-disciplinary open access archive for the deposit and dissemination of scientific research documents, whether they are published or not. The documents may come from teaching and research institutions in France or abroad, or from public or private research centers.
L'archive ouverte pluridisciplinaire HAL, est destinée au dépôt et à la diffusion de documents scientifiques de niveau recherche, publiés ou non, émanant des établissements d'enseignement et de recherche français ou étrangers, des laboratoires publics ou privés. 


\title{
PROBLEMS ENCOUNTERED DURING THE UP-GRADING TRANSFORMATION OF THE FN-TANDEM OF SACLAY
}

\author{
L. BIANCHI, B. DELAUNAY, J. P. FOUAN, J. GASTEBOIS and J. L. GIRMA \\ D. Ph. N./BE, C.E.N. Saclay, B.P. 2, 91190 Gif-sur-Yvette, France
}

\begin{abstract}
Résumé. - Les problèmes rencontrés lors de transformation du Tandem FN de Saclay sont exposés.
Abstract. - We report on the problems encontred during the up grading of the Saclay FN Tandem.
\end{abstract}

The up-grading transformation of the Saclay FNTandem was planned last year. It began in April 1976, using the up-grading kit provided by H.V.E.C.: replacement of the aluminum electrode accelerating tube by a new one with stainless steel electrodes, and the old (yellow) resistors of the column by a set of new (blue) resistors (the same as those used on MP machines). We have been very soon faced with two main problems.

The first one was the behaviour of the vacuum conditions as a function of time. The stainless steel tube was first mounted with buna o-rings, of the same kind as those previously used on the aluminum tube. The method used to check the vacuum quality was:

1) to achieve a good vacuum inside the tube,

2) to close the gate valve, and wait for ten minutes without pumping,

3) to measure the pressure rise in the tube,

4) to open the gate valve, and wait again for a good vacuum.

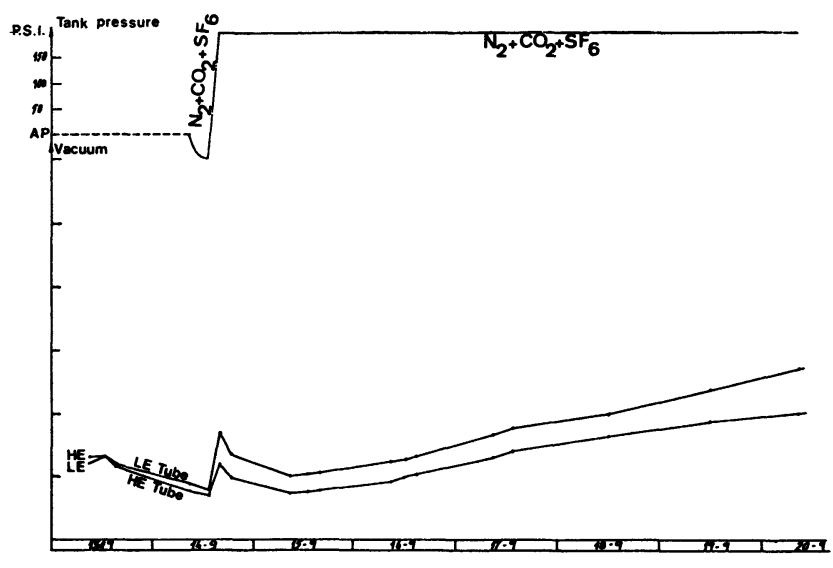

FIG. 1. - Rates of pressure rise in the tube, as a function of time, when using buna O-rings. The L.E. and H.E. parts were independant of each other. The corresponding tank pressure is shown in the upper part of the figure.
The measurements were done separately on the L.E. and H.E. sections. Figure 1 shows how these rises of pressure increased continuously with time, over a period of several days, and simultaneously in each part of the tube. Figure 2 shows a comparison between the L.E. and H.E. behaviours, when the H.E. part was totally equiped with viton O-rings, whereas the L.E. one had still buna O-rings.

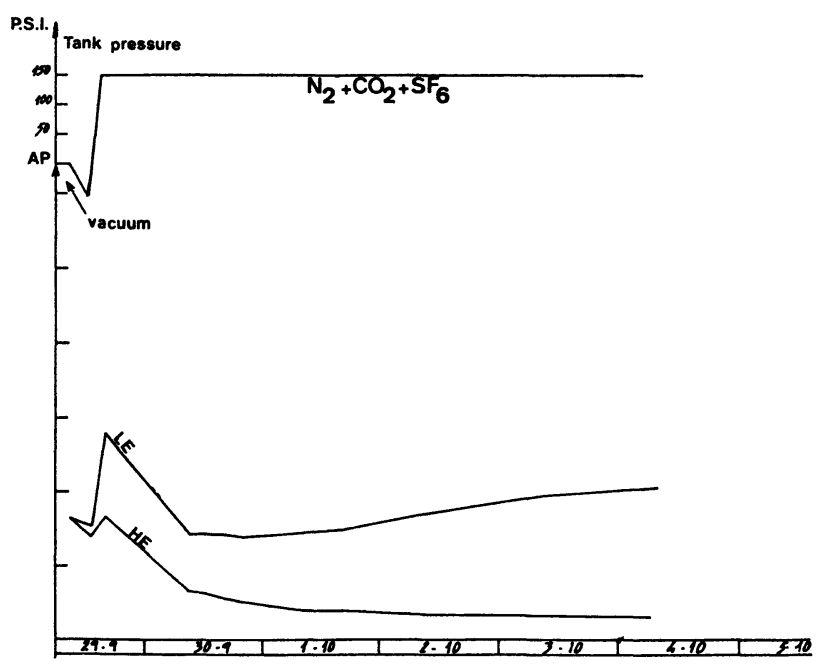

Fig. 2. - The same as figure 1, excepted that the H.E. part was equiped with viton O-rings.

In order to investigate further, it was decided to connect a mass spectrometer to the vacuum system. Results of gas analysis are presented:

- in figures 3 and 4, concerning the L.E. part, equiped with buna O-rings. A huge increase of mass 44 intensity was observed,

- in figures 5 and 6, concerning the H.E. part, equiped with viton $\mathrm{O}$-rings. No visible effect was observed. 


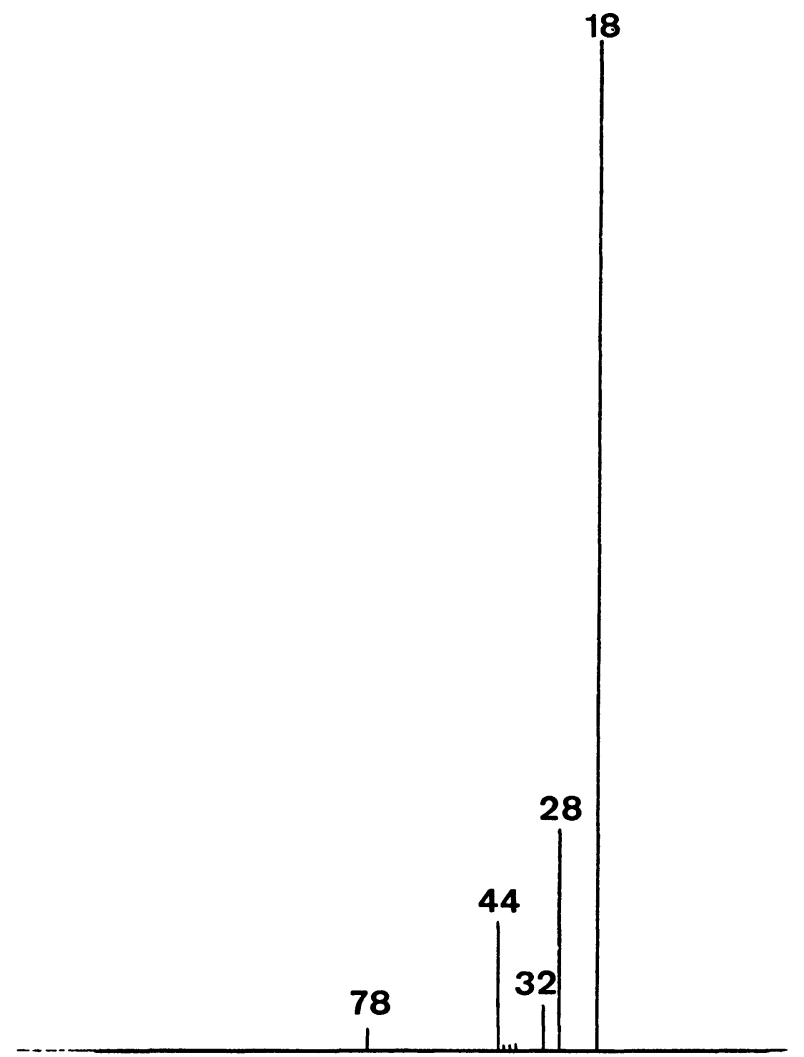

FIG. 3. - Reference mass spectrum for the measurement shown in figure 4.

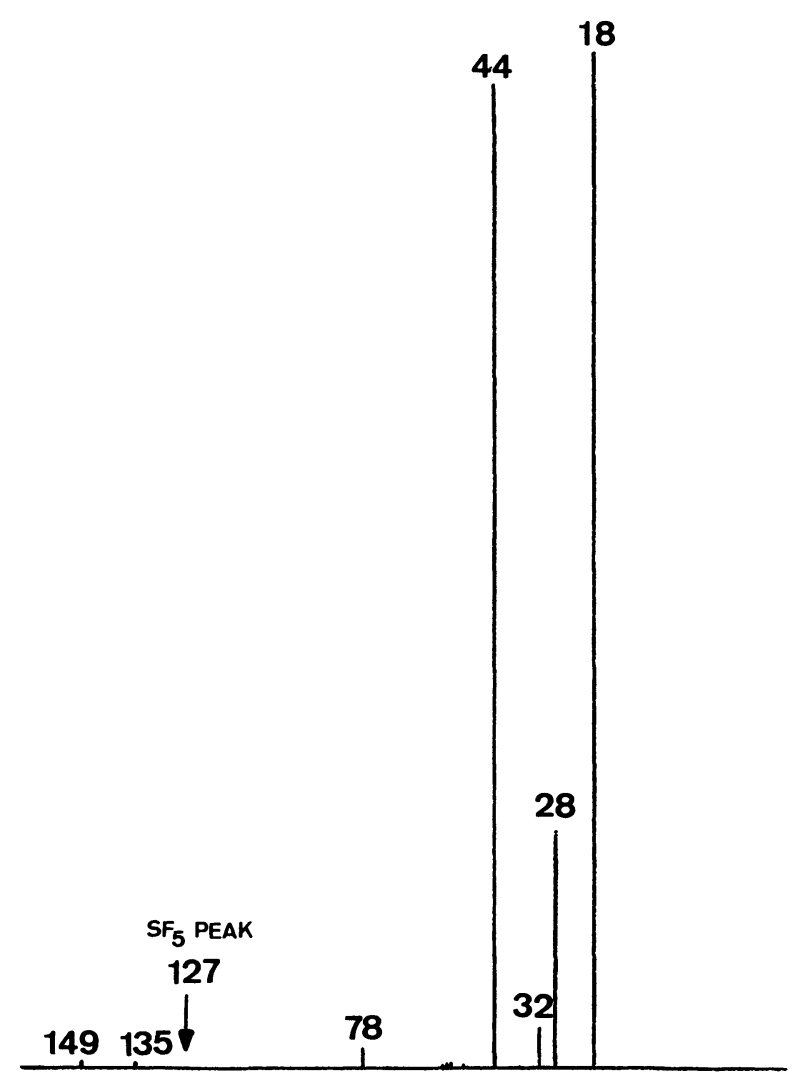

FIG. 4. - Mass intensities obtained when connecting the mass spectrometer to the L.E. part of the tube, equiped with buna $\mathrm{O}$ rings.

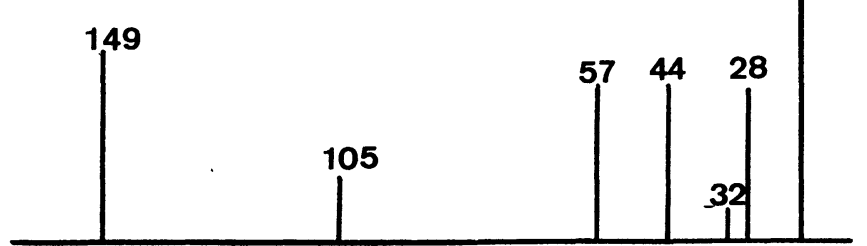

FIG. 5. - Reference mass spectrum for the measurement shown in figure 6.

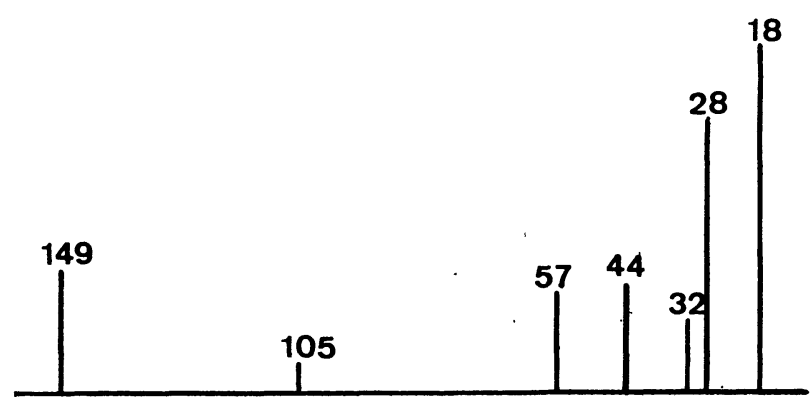

FIG. 6. - Mass intensities obtained when connecting the mass spectrometer to the H.E. part of the tube, equiped with viton Orings.

There is no indication of any SF6 presence in both cases. (The insulating gas was $\mathrm{N} 2+\mathrm{CO} 2+\mathrm{SF} 6$ mixture, with respective volume proportions of $56 \%$, $14 \%$ and $30 \%$ ).

It was then concluded that buna O-rings presented a selective permeability to $\mathrm{CO} 2$, which was much more important than the one relative to viton O-rings. This was, indeed, confirmed by already known values of permeabilities, presented in table I. One sees that butyl is even better than viton.

\section{TABLE I}

Permeability of polymers*

Polymers Gases

$\begin{array}{lccc}- & \text { Nitrogen } & \begin{array}{c}- \\ \text { Oxygen }\end{array} & \begin{array}{c}\text { Carbon } \\ \text { dioxide }\end{array} \\ \text { Butyl rubber } & 3.2 & 13 & 52 \\ \text { Viton A } & 4.4 & 15 & 78 \\ \text { Buna S } & 63.5 & 172 & 1240\end{array}$

Units: cc. $(\mathrm{STP}) / \mathrm{cm}^{2} / \mathrm{mm} / \mathrm{s} / \mathrm{cm} / \mathrm{Hg} \times 10^{10}$

(*) From: Modern Plastics, march 1966, p. 141.

Once this first problem has been solved, a second one appeared. It was found impossible to increase the voltage higher than $6.5 \mathrm{MV}$, without getting large instabilities, continuous sparks, and a prohibitive 
radiation level all along the L.E. sections (all that without any beam). A carefull inspection of the sparkgaps of the mounted column resistors revealed that all gaps were seriously marked by important sparks (each resistor set has 10 gaps in series, instead of a single one in the case of the old yellow resistors). So, in spite of a theoretically better stability of the voltage because of this new geometry of the spark-gaps, the effect was the opposite, once mounted on the column and coupled to the tube. It is not yet understood why this is so, whereas there seems to be no problem in the MP machines. It may be due to the fact that MP insulating gas is pure SF6, but it has still to be proved.

Our instability problem was overcome immediately by replacing the whole set of resistors by the set of old ones, and a voltage of $9 \mathrm{MV}$. is now easily achieved, since two months, without any spark and any radiation. 